Article

\title{
The Effects of Macroeconomic Factors on Road Traffic Safety: A Study Based on the ARDL-ECM Model
}

\author{
Xibing $\mathrm{Li}^{1}{ }^{1}$, Jiao Liu ${ }^{1, *}$, Jian Zhou ${ }^{1} \mathbb{C}$, Xiling Liu ${ }^{1}$, Lei Zhou ${ }^{2}$ and Wei Wei ${ }^{1}$ \\ 1 School of Resources and Safety Engineering, Central South University, Changsha 410083, China; \\ xbli@csu.edu.cn (X.L.); csujzhou@hotmail.com (J.Z.); lxlenglish@163.com (X.L.); \\ Weiw1987@outlook.com (W.W.) \\ 2 Bureau of Ecology and Environment, Changsha 410000, China; zhoulei5382@163.com \\ * Correspondence: smilyivy@csu.edu.cn
}

Received: 9 November 2020; Accepted: 4 December 2020; Published: 9 December 2020

\begin{abstract}
This paper attempts to examine whether socioeconomic volatility produces differentiated effects on road traffic accident indicators. Adopting the Autoregressive distributed lag error-correction model (ARDL-ECM), this paper explores the long-term equilibrium and short-term interactions between five common economic indicators, namely, average salaries (AS), employment (EM), unemployment (UE), total mileage of highway (TMH), and private vehicle ownership (PVO), as well as road traffic-related indicators including the number of road traffic accidents (RTA), injuries (IN), fatalities (FA), and direct economic losses (DEL), using data of road traffic accidents spanning from 1999 to 2018 in China. The study found that all economic indicators except average salaries showed a long-term equilibrium with road traffic accident indicators. The Granger causality test showed that, over the short term, an increase in employment could lead to an increase in injuries, and an increase in private vehicle ownership could cause a rise in fatalities. This study demonstrates that the volatility in economic indicators indeed produces differentiated effects on road traffic accident indicators, providing a theoretical basis for improving road safety performance and formulating relevant policies.
\end{abstract}

Keywords: road traffic safety; macroeconomic; injuries; fatalities; ARDL-ECM model

\section{Introduction}

Road safety performance represents one of the most fundamental indicators for the maturity of a motorized society across the world [1]. Despite people's longtime commitment to higher road safety performance and lower traffic accident rates, traffic accidents are still one of the major public safety issues. Each year, millions of people are injured and more than 1.3 million are killed in road traffic accidents around the world [2].

Studies show that macroeconomic factors are closely related to road traffic accidents [3,4]. In this area, a large body of scholarly research has been conducted in order to determine the specific economic indicators influencing road traffic accidents. In particular, gross domestic product (GDP) per capita as an important indicator measuring the level of regional economic development has drawn extensive research attention [5]. By comparing GDP per capita and traffic accident fatality rates in 27 European countries, George Yannis [6] found that GDP per capita was positively correlated with traffic accident fatality rate and increased GDP per capita would lead to a rise in the traffic accident fatality rate. A study conducted by Douglas J. Wiebe [7] concluded that GDP growth resulted in a rise in the number of fatalities caused by road traffic accidents. Iman Dadgar [8] examined the relationship between GDP and traffic accident fatality rates in 18 Organisation for Economic Co-operation and Development (OECD) member countries, finding that for every $\$ 1000$ increase in GDP per capita, the traffic fatality 
rate increased by $0.58 \%$ over the short term and $1.59 \%$ over the long term. Empirical analyses focusing on Spain [9] and other European regions [10] also found that changes in GDP per capita affect road traffic accidents.

Another intensively researched indicator that is closely associated with economy is the unemployment rate. By analyzing the traffic accident data of Queensland in Australia spanning from 1958 to 2007, Son Nghiem [11] found that for every 1\% decrease in the unemployment rate, fatalities caused by traffic accidents dropped by $0.2 \%$. A study from Virginia found that every $1 \%$ increase in the unemployment rate was associated with a reduction of as many as around 2500 traffic accidents [12]. Furthermore, the Kuznets hypothesis regarding road traffic accidents has also received intensive scholarly attention $[13,14]$. In particular, the Kuznets relationship between traffic accidents and per capita income has been repeatedly demonstrated [15-17], which posits that traffic accidents exhibit a growing trend in the early stage of economic growth but will be effectively inhibited as economic growth continues and improvements in policy and infrastructure are achieved. In the meantime, there have also been studies showing that economic volatility affects government budgets, which in turn leads to changes in road traffic accidents [18-20]. Subject to the effect of multiple economic crises over recent years, the cyclical interactions between economic volatility and road traffic accidents have gained broader attention, and factors like alcohol taxes [21] and vehicle miles traveled [22] have also been proven to exert different degrees of impact on road traffic accidents.

The majority of recent studies have explored the effects of macroeconomic factors on road traffic accidents by using single indicators like the number of road traffic accidents or fatalities. In fact, we found that a same economic factor may produce differentiated effects on the number of road traffic accidents, injuries, or fatalities. Thus, it is necessary to discriminate the effect of economic factors on road traffic accidents depending on different indicators pertaining to accidents in order to better understand both the short- and long-term effects of macroeconomic factors on road traffic accidents, thereby proposing effective measures.

Despite the extensive attention paid to the relationship between macroeconomic factors and road traffic accidents, most current studies are concentrated on developed countries or regions [23,24], and very few studies have focused on cases from developing countries. In reality, most accidents associated with fatalities and injuries occur in low- and middle-income countries [25]. A report published by the World Health Organization (WHO) suggests that no low-income country had reduced the number of road traffic deaths from 2013 to 2016 [2]. This research selects China-specific data of road traffic accidents spanning two decades, with a view of filling in the blank of this type of research by providing a case pertaining to developing countries.

As the world's largest developing country, China witnessed about 241,734 road traffic accidents in 2018, which caused 61,832 deaths, 256,425 injuries, and a direct economic loss of around 1364.9 million yuan, representing a substantially higher traffic accident rate than developed countries [26]. Since the turn of the 21st century, China has sustained relatively high economic growth rates. Accompanying this trend are not only a more sophisticated infrastructure for road traffic, a continuous growth in private vehicle ownership and an increasing number of drivers and road traffic flow, but also increasingly salient traffic safety problems. To further reduce road traffic accidents, the Chinese government has instituted a series of policies. Despite the generally stable performance of road traffic safety in China, major or extraordinarily serious road traffic accidents causing mass injuries or deaths still happen from time to time.

Focusing on road traffic accidents over the past two decades in China, this research employs econometric approaches to discuss the differentiated effects of economic factors on the number of road traffic accidents, injuries, fatalities and direct economic losses with an attempt to gain an insight into the specific effects of economic factors on road traffic safety, thereby proposing more effective and robust measures. 


\section{Data Selection}

In this study, macroeconomic factors and road traffic accident indicators over the period of 1999-2018 were adopted. All these data were collected from the China National Bureau of Statistics [27] website. Table 1 describes the study data, including a variable description, abbreviations, and period. Table 2 is the original data for macroeconomic factors and road traffic accident indicators.

Figure 1 shows the variation trends of road traffic accidents (RTA), injuries (IN), fatalities (FA), and direct economic losses (DEL) between 1999 and 2018. Specifically, RTA, IN and FA presented an increasing trend year over year after 1999, and peaked in 2002 at 773,137, 562,074 and 109,381, respectively, followed by a declining trend and then a minor rebound after 2015. Comparatively, DEL peaked at CNY 3.369 billion in 2003.

Table 1. List of variables of annual data used.

\begin{tabular}{|c|c|c|c|}
\hline \multicolumn{2}{|c|}{ Variable } & Description & Abbreviations \\
\hline \multirow{4}{*}{$\begin{array}{l}\text { Road traffic } \\
\text { accident indicators }\end{array}$} & Road traffic accidents & Total road traffic accidents & RTA \\
\hline & Injuries & $\begin{array}{l}\text { Total number of injuries caused by } \\
\text { road traffic accidents }\end{array}$ & IN \\
\hline & Fatalities & $\begin{array}{l}\text { Total number of deaths caused by } \\
\text { road traffic accidents }\end{array}$ & FA \\
\hline & Direct economic losses & $\begin{array}{l}\text { Expenses incurred in connection } \\
\text { with personal injuries and deaths } \\
\text { caused by road traffic accidents } \\
\text { and post-accident treatment, as } \\
\text { well as the value of damaged } \\
\text { properties, including expenses } \\
\text { paid for personal injuries and } \\
\text { deaths, post-accident treatment, } \\
\text { and property losses }\end{array}$ & DEL \\
\hline \multirow{5}{*}{$\begin{array}{l}\text { Potential relevant } \\
\text { macroeconomic factors }\end{array}$} & Average salaries & $\begin{array}{l}\text { Average monetary salary per } \\
\text { employed worker during a certain } \\
\text { period of time }\end{array}$ & AS \\
\hline & Employment & $\begin{array}{c}\text { Total employed persons within } \\
\text { the region }\end{array}$ & $\mathrm{EM}$ \\
\hline & Unemployment & $\begin{array}{l}\text { Total unemployed persons within } \\
\text { the region }\end{array}$ & UE \\
\hline & Total mileage of highway & $\begin{array}{l}\text { Including inter-city, urban-rural, } \\
\text { and rural public roads allowing } \\
\text { motorized vehicles to travel, the } \\
\text { total length of highway running } \\
\text { through urban streets, the lengths } \\
\text { of highway bridges and tunnels, } \\
\text { and the width of ferry lanes }\end{array}$ & $\mathrm{TMH}$ \\
\hline & $\begin{array}{l}\text { Private vehicle } \\
\text { ownership }\end{array}$ & $\begin{array}{l}\text { The number of vehicles registered } \\
\text { with the traffic management } \\
\text { authorities under public security } \\
\text { bureaus and assigned with local } \\
\text { private vehicle number plates }\end{array}$ & $\mathrm{PVO}$ \\
\hline
\end{tabular}


Table 2. Original data for macroeconomic factors and road traffic accident indicators.

\begin{tabular}{|c|c|c|c|c|c|c|c|c|c|}
\hline Year & RTA & FA & IN & $\begin{array}{c}\text { DEL } \\
\text { (Million/CNY) }\end{array}$ & $\begin{array}{c}\text { EM } \\
\text { (Million) }\end{array}$ & $\begin{array}{c}\text { UE } \\
\text { (Million) }\end{array}$ & $\begin{array}{c}\text { AS } \\
\text { (CNY) }\end{array}$ & $\begin{array}{l}\text { TMH (Thousand } \\
\text { Kilometer) }\end{array}$ & $\begin{array}{c}\text { PVO } \\
\text { (Million) }\end{array}$ \\
\hline 1999 & 412,860 & 83,529 & 286,080 & 2124.02 & 713.94 & 5.75 & 8524 & 1351.7 & 5.3388 \\
\hline 2000 & 616,971 & 93,853 & 418,721 & 2632.9 & 720.85 & 5.95 & 9333 & 1679.8 & 6.2533 \\
\hline 2001 & 754,919 & 105,930 & 546,485 & 3087.87 & 727.97 & 6.81 & 10,834 & 1698 & 7.7078 \\
\hline 2002 & 773,137 & 109,381 & 562,074 & 3324.38 & 732.8 & 7.7 & 12,373 & 1765.2 & 9.6898 \\
\hline 2003 & 667,507 & 104,372 & 494,174 & 3369.15 & 737.36 & 8 & 13,969 & 1809.8 & 12.1923 \\
\hline 2004 & 517,889 & 107,077 & 480,864 & 2391.41 & 742.64 & 8.27 & 15,920 & 1870.7 & 14.8166 \\
\hline 2005 & 450,254 & 98,738 & 469,911 & 1884.01 & 746.47 & 8.39 & 18,200 & 3345.2 & 18.4807 \\
\hline 2006 & 378,781 & 89,455 & 431,139 & 1489.56 & 749.78 & 8.47 & 20,856 & 3457 & 23.3332 \\
\hline 2007 & 327,209 & 81,649 & 380,442 & 1198.78 & 753.21 & 8.3 & 24,721 & 3583.7 & 28.7622 \\
\hline 2008 & 265,204 & 73,484 & 304,919 & 1009.72 & 755.64 & 8.86 & 28,898 & 3730.2 & 35.0139 \\
\hline 2009 & 238,351 & 67,759 & 275,125 & 914.37 & 758.28 & 9.21 & 32,244 & 3860.8 & 45.7491 \\
\hline 2010 & 219,521 & 65,225 & 254,075 & 926.34 & 761.05 & 9.08 & 36,539 & 4008.2 & 59.3871 \\
\hline 2011 & 210,812 & 62,387 & 237,421 & 1078.73 & 764.2 & 9.22 & 41,799 & 4106.4 & 73.2679 \\
\hline 2012 & 204,196 & 59,997 & 224,327 & 1174.9 & 767.04 & 9.17 & 46,769 & 4237.5 & 88.386 \\
\hline 2013 & 198,394 & 58,539 & 213,724 & 1038.97 & 769.77 & 9.26 & 51,483 & 4356.2 & 105.0168 \\
\hline 2014 & 196,812 & 58,523 & 211,882 & 1075.43 & 772.53 & 9.52 & 56,360 & 4463.9 & 123.3936 \\
\hline 2015 & 187,781 & 58,022 & 199,880 & 1036.92 & 774.51 & 9.66 & 62,029 & 4577.3 & 140.991 \\
\hline 2016 & 212,846 & 63,093 & 226,430 & 1207.6 & 776.03 & 9.82 & 67,569 & 4696.3 & 163.3022 \\
\hline 2017 & 203,049 & 63,772 & 209,654 & 1213.11 & 776.4 & 9.72 & 74,318 & 4773.5 & 185.1511 \\
\hline 2018 & 244,937 & 63,194 & 258,532 & 1384.56 & 775.86 & 9.74 & 82,413 & 4846.5 & 205.7493 \\
\hline
\end{tabular}

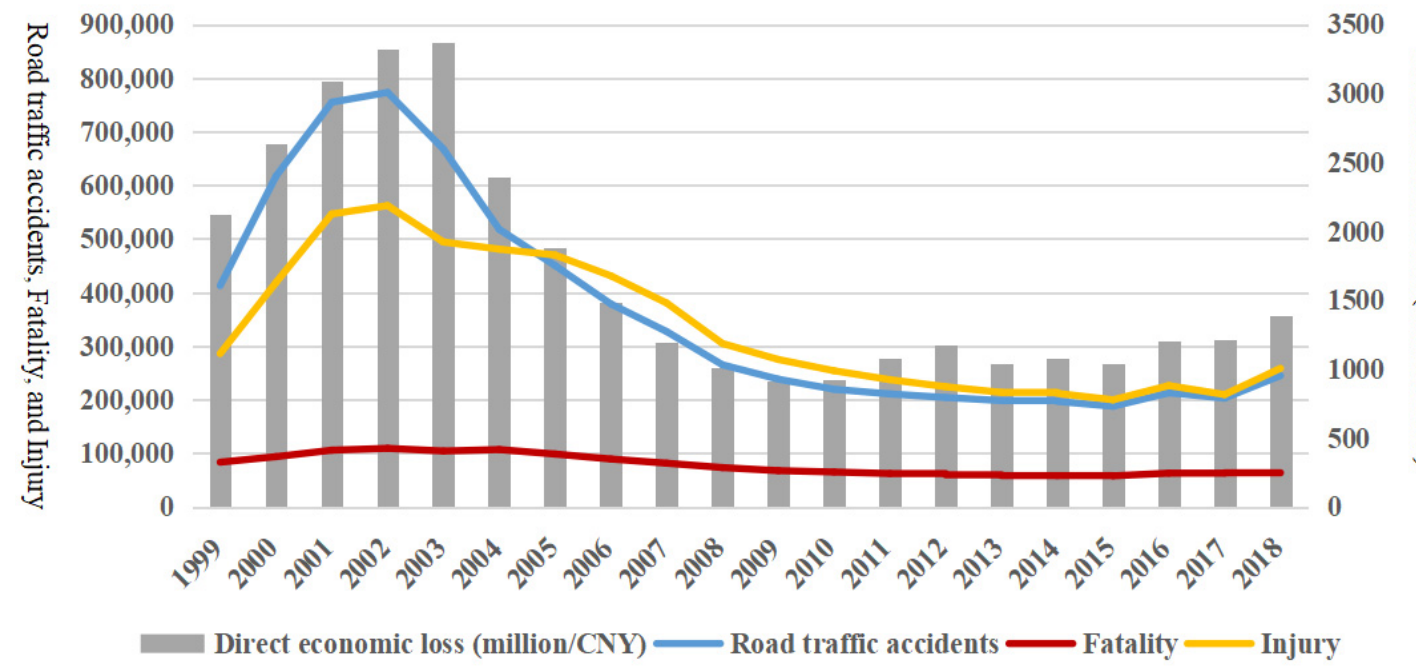

Figure 1. Road traffic accidents (RTA), injuries (IN), fatalities (FA) and direct economic losses (DEL) over time (1999-2018).

By comparing road traffic accident data between 1999 and 2018, we found that, in terms of accident types, noticeable changes occurred to accidents causing injuries and fatalities. In particular, the share of injuries caused by accidents of non-motorized vehicles (e.g., bicycles, manually assisted vehicles) dropped to $1 \%$ from $11 \%$, although the shares of injuries caused by car and motorbike accidents remain unchanged (Figure 2a).With respect to the number of fatalities, the share of fatalities caused by vehicle-induced accidents rose to $75 \%$ from $60 \%$ in 1999 , while the share of fatalities caused by pedestrian-induced accidents dropped to $2 \%$ from $7 \%$ in 1999 (Figure 2b). 
1999

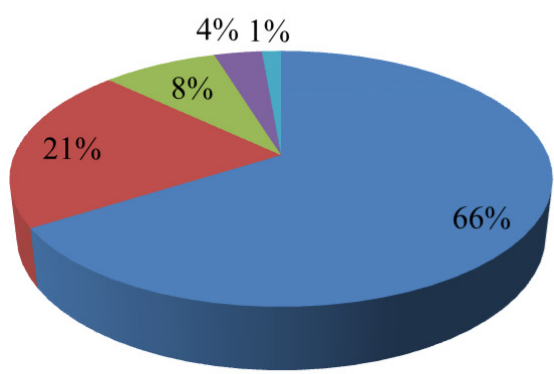

a)

1999

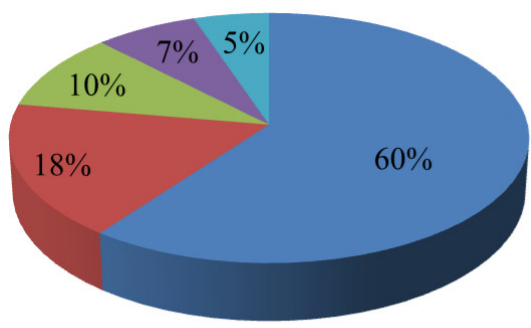

2018

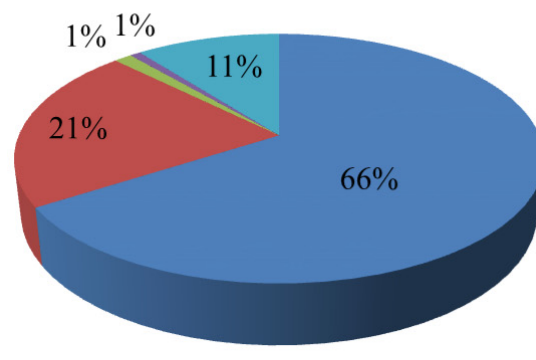

a)

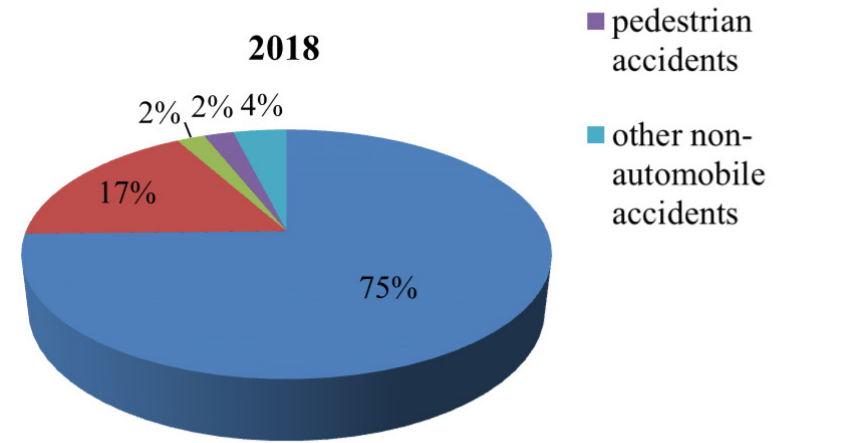

b)

Figure 2. (a) The injuries are distributed by type of road traffic accident (1999 and 2018); (b) The fatalities are distributed by type of road traffic accident (1999 and 2018).

For the sake of cross-sectional reference, we selected five macroeconomic factors that have been intensively adopted in previous studies $[10,16]$. Figure 3 presents the distributions of average salaries (AS), the number of employed persons (employment (EM)) and the number of unemployed persons (unemployment (UE)) in China from 1999 to 2018. For variation trends of total mileage of highway $(\mathrm{TMH})$ and private vehicle ownership (PVO), see Figure 4. All these five groups of time series have exhibited a fluctuant rising trend over recent years.

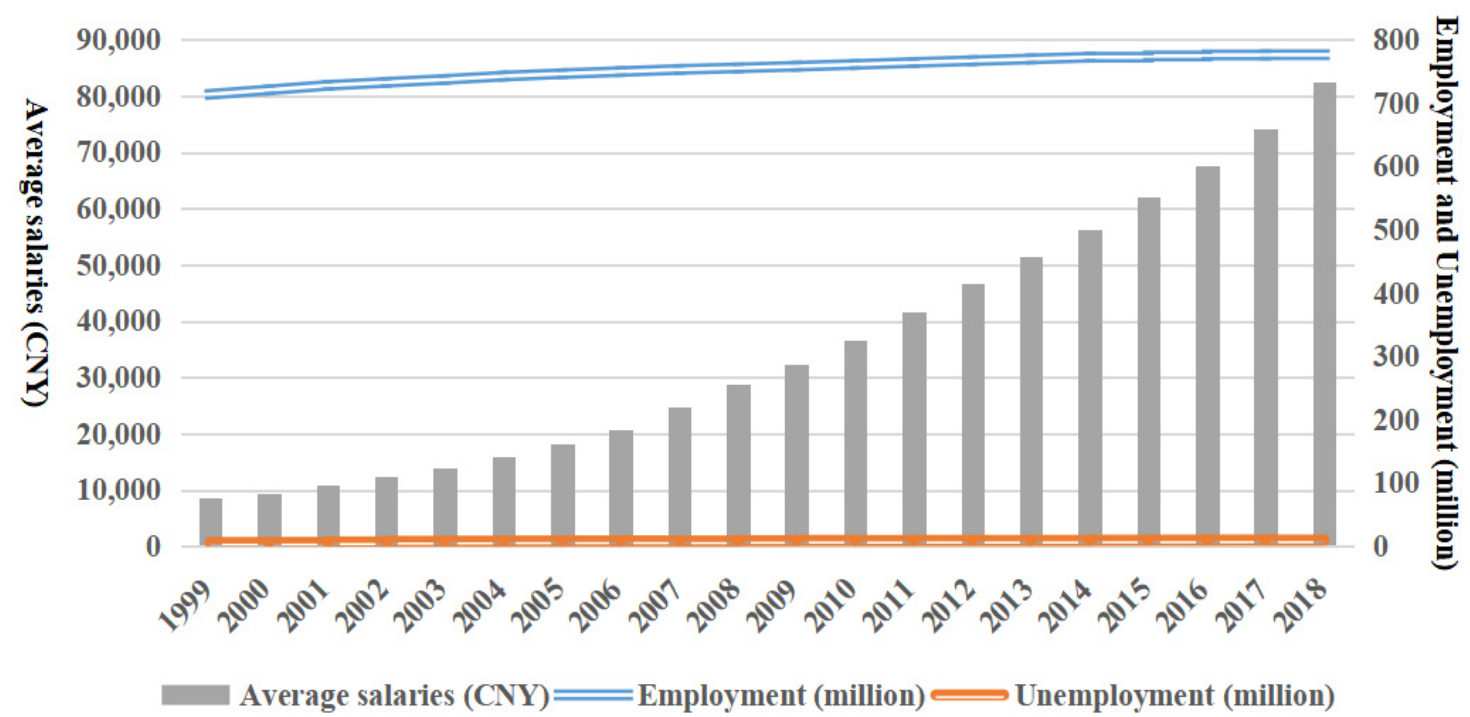

Figure 3. Average salaries (AS), employment (EM), and unemployment (UE) over time (1999-2018). 


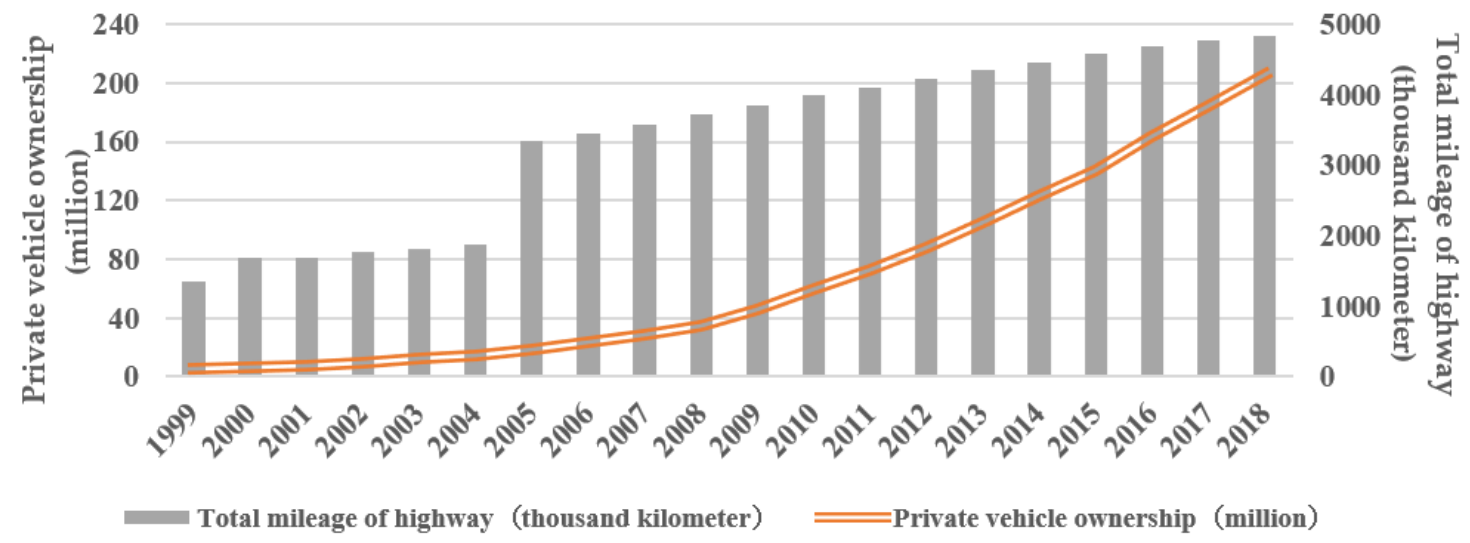

Figure 4. Total mileage of highway (TMH) and private vehicle ownership (PVO) over time (1999-2018).

\section{Empirical Analysis}

Presently, the most commonly seen cointegration tests include the Engle-Granger cointegration test [28], the Johansen's cointegration test [29] and the Autoregressive distributed lag (ARDL) bound test [30]. The former two approaches are more suitable for data with large sample sizes, which require the time series to be cointegrated of order 1 or 0 , that is, all variables must be $I(0)$ or $I(1)$. Comparatively, the ARDL bound test entails lower requirements on sample sizes, and its robustness is not affected by small sample sizes. Furthermore, this test also has a lower requirement on time series, and cointegration tests can be conducted on time series either being $I(0), I(1)$, or mixed integrals using the ARDL bound approach. In addition, the ARDL bound cointegration test can simultaneously estimate long- and short-term effects. As such, this paper utilizes the ARDL bound cointegration approach to test the effects of economic volatility on road traffic accident indicators. Figure 5 shows a diagram of the five phases of this study. Based on the data selection and preprocessing in the previous section, we first determined all variables as being $I(0)$ or $I(1)$ through unit root tests. Second, we used the ARDL bound test to examine the cointegration of variables, and estimate the long-run and short-run elasticity by the ARDL and error-correction model (ECM). Lastly, we used the vector error correction model (VECM)-based Granger causality analysis to check the direction of causal relationships among the variables.

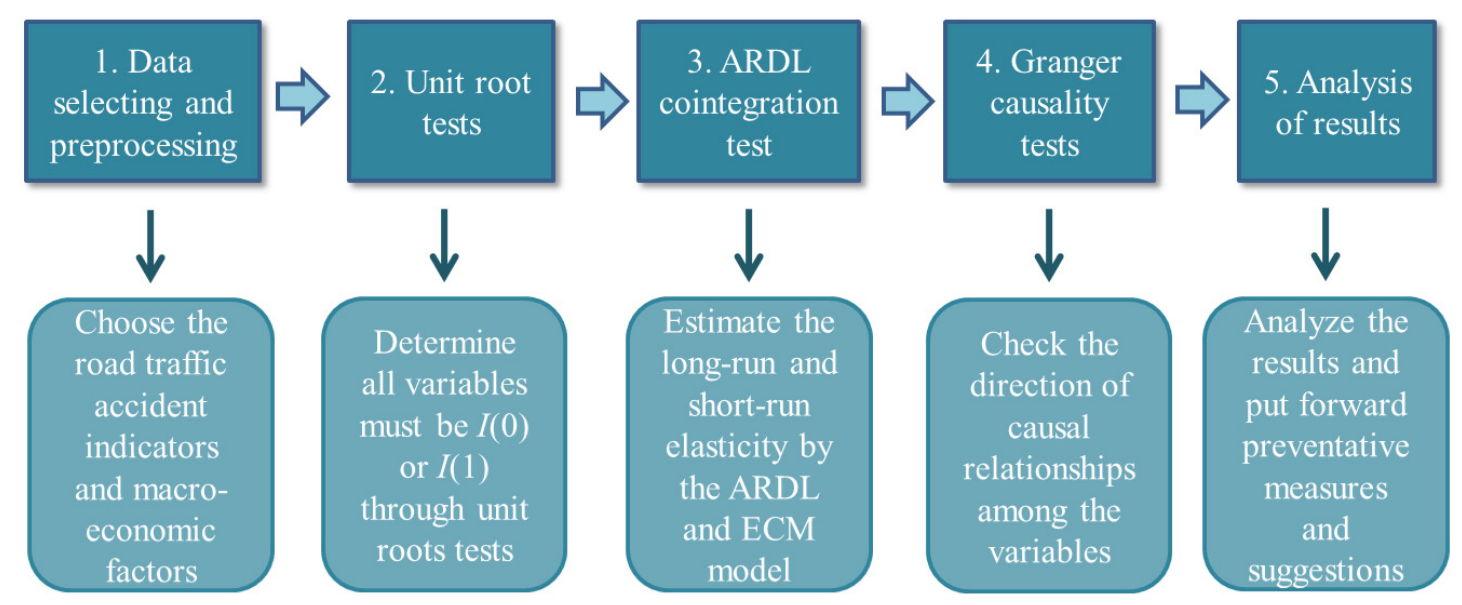

Figure 5. Main phases of this study. 
The ARDL equation for our study is presented as follows:

$$
\begin{aligned}
& \Delta \operatorname{InX}=c_{0}+\sum_{i=1}^{p 1} \alpha_{1} \Delta \operatorname{InRT} A_{t-i}+\sum_{i=1}^{p 2} \alpha_{2} \Delta \operatorname{InIN} N_{t-i}+\sum_{i=1}^{p 3} \alpha_{3} \Delta \operatorname{InF} A_{t-i}+\sum_{i=1}^{p 4} \alpha_{4} \Delta \operatorname{InDEL} L_{t-i} \\
& +\lambda_{1} \operatorname{InRTA}_{t-1}+\lambda_{2} \operatorname{InIN}_{t-1}+\lambda_{3} \operatorname{InFA} A_{t-1}+\lambda_{4} \operatorname{InDEL_{t-1}}+\varepsilon_{t}
\end{aligned}
$$

where AS, ES, UE, TMH, and PVO are denoted by $X$, respectively. The first difference operator is denoted by $\Delta$, and the natural logarithmic form of the variable is denoted by $I n$. The lag lengths are denoted by $p 1, p 2, p 3$, and $p 4$, the white noise error term is denoted by $\varepsilon_{t}$, and the time series operator is denoted by $t$, where $\alpha_{1}, \alpha_{2}, \alpha_{3}$, and $\alpha_{4}$ are short- or long-run multipliers for RTA, IN, FA, and DEL, respectively. We also framed two types of hypotheses from Equation (1), representing long-run relationships, the first of which is the null hypothesis of no cointegration $\left(H_{0}: \lambda_{1}=\lambda_{2}=\lambda_{3}=\lambda_{4}=0\right)$ and the second of which is the alternative hypothesis $\left(H_{1}: \lambda_{1} \neq \lambda_{2} \neq \lambda_{3} \neq \lambda_{4} \neq 0\right)$. If the null hypothesis is rejected, the short-run and long-run relationships among macroeconomic factors and road traffic accident indicators can be estimated by the model since the long-term equilibrium relationship exists. The optimal lag order in the model is defined by the Akaike information criterion (AIC) and the Schwarz-Bayesian criterion (SBC).

The second step is to estimate the long-run and short-run elasticity by the ARDL and ECM model. For the long-run coefficients, ARDL models are listed in Equation (2). The short-run dynamic coefficients are obtained by the corresponding ECM model as Equation (3):

$$
\begin{gathered}
\Delta \operatorname{InX}=c_{0}+\sum_{i=1}^{p 1} \alpha_{1} \Delta \operatorname{InRT} A_{t-i}+\sum_{i=1}^{p 2} \alpha_{2} \Delta \operatorname{InIN} N_{t-i}+\sum_{i=1}^{p 3} \alpha_{3} \Delta \operatorname{InF} A_{t-i}+\sum_{i=1}^{p 4} \alpha_{4} \Delta \operatorname{InDEL} L_{t-i} \\
+\varepsilon_{t}
\end{gathered}
$$

where $\mu_{t}$ is the error correction term and stands for the speed of adjustment from convergence to equilibrium.

The ARDL-ECM results provide information about the long-run and short-run dynamics but do not provide the direction of the relationships, which is essential to develop policy implications. Therefore, we used the vector error correction model (VECM)-based [31] Granger causality analysis [32] to check the direction of causal relationships among the variables. The VECM Granger causality approach conveys the short-run as well as the long-run causality among the variables. The VECM Granger causality is formulated through Equation (4):

$$
\left[\begin{array}{c}
\Delta I n X_{t} \\
\Delta I n R T A_{t} \\
\Delta I n I N_{t} \\
\Delta I n F A_{t} \\
\Delta I n D E L_{t}
\end{array}\right]=\left[\begin{array}{c}
\delta_{1} \\
\delta_{2} \\
\delta_{3} \\
\delta_{4} \\
\delta_{5}
\end{array}\right]+\sum_{p-1}^{q}\left[\begin{array}{c}
\theta_{11 p} \theta_{12 p} \theta_{13 p} \theta_{14 p} \theta_{15 p} \\
\theta_{21 p} \theta_{22 p} \theta_{23 p} \theta_{24 p} \theta_{25 p} \\
\theta_{31 p} \theta_{32 p} \theta_{33 p} \theta_{34 p} \theta_{35 p} \\
\theta_{41 p} \theta_{42 p} \theta_{43 p} \theta_{44 p} \theta_{45 p} \\
\theta_{51 p} \theta_{52 p} \theta_{53 p} \theta_{54 p} \theta_{55 p}
\end{array}\right] \times\left[\begin{array}{c}
\Delta I n X_{t-p} \\
\Delta I n R T A_{t-p} \\
\Delta I n I N_{t-p} \\
\Delta I n F A_{t-p} \\
\Delta I n D E L_{t-p}
\end{array}\right]+\left[\begin{array}{c}
\alpha_{1} \\
\alpha_{2} \\
\alpha_{3} \\
\alpha_{4} \\
\alpha_{5}
\end{array}\right] E C T_{i t-1}+\left[\begin{array}{c}
\mu_{1 t} \\
\mu_{2 t} \\
\mu_{3 t} \\
\mu_{4 t} \\
\mu_{5 t}
\end{array}\right]
$$

where $\Delta$ is the first difference operator, $p$ is the lag length, and $\mu$ is the error correction term.

\section{Results and Discussion}

\subsection{Unit Root Tests}

The augmented Dickey-Fuller (ADF) [33] and Phillips-Perron (PP) [34] tests were selected in this study. As listed in Table 3, the results of the ADF test show that all of the series conform to $I(0)$ or $I(1)$, and the results of the PP test show that all variables conform to $I(1)$ except private vehicle population 
and average salaries. The results of the PP test allow us to apply any method of cointegration tests as all of the series fit $I(1)$. However, the results of the ADF test indicate that all of the series are integrated at $I(0)$ or I(1); therefore, only the ARDL bound cointegration test can be applied.

Table 3. Results of the augmented Dickey-Fuller (ADF) and Phillips-Perron (PP) unit root tests.

\begin{tabular}{|c|c|c|c|c|c|c|c|c|c|c|c|c|}
\hline \multirow{3}{*}{ Variable } & \multicolumn{6}{|c|}{ ADF Test } & \multicolumn{6}{|c|}{ PP Test } \\
\hline & \multicolumn{3}{|c|}{ Level } & \multicolumn{3}{|c|}{ First Difference } & \multicolumn{3}{|c|}{ Level } & \multicolumn{3}{|c|}{ First Difference } \\
\hline & $t$-Value & $p$ & $I(0)$ & $t$-Value & $p$ & $I(1)$ & $t$-Value & $p$ & $I(0)$ & $t$-Value & $p$ & $I(\mathbf{1})$ \\
\hline RTA & -5.9871 & 0.0002 & YES & -2.7375 & 0.0112 & YES & -0.5854 & 0.4503 & $\mathrm{NO}$ & -3.0986 & 0.0040 & YES \\
\hline IN & -5.0755 & 0.0022 & YES & -809.0152 & 0.0001 & YES & -3.2998 & 0.0963 & NO & -3.3711 & 0.0021 & YES \\
\hline FA & -0.9856 & 0.2781 & $\mathrm{NO}$ & -2.9305 & 0.0059 & YES & -2.3419 & 0.3943 & NO & -2.8792 & 0.0066 & YES \\
\hline DEL & -3.0905 & 0.0466 & YES & -2.6530 & 0.0111 & YES & -0.4987 & 0.4866 & NO & -2.6783 & 0.0105 & YES \\
\hline EM & -2.1425 & 0.2325 & NO & -7.8469 & 0.0004 & YES & 4.7709 & 1 & NO & -3.0781 & 0.0042 & YES \\
\hline UE & -5.6648 & 0.0032 & YES & -28.7953 & 0.0001 & YES & -10.2385 & 0 & YES & -1.7892 & 0.0706 & YES \\
\hline TMH & -4.5323 & 0.0045 & YES & -28.3829 & 0.0001 & YES & -2.1153 & 0.2412 & NO & -3.8421 & 0.0007 & YES \\
\hline PVO & -3.0419 & 0.0499 & YES & -1.9058 & 0.6077 & NO & 1.3783 & 0.9999 & NO & -2.5041 & 0.3222 & $\mathrm{NO}$ \\
\hline AS & -1.9444 & 0.306 & $\mathrm{NO}$ & -10.9525 & 0.0001 & YES & -3.9072 & 0.0085 & YES & -1.8279 & 0.0654 & $\mathrm{NO}$ \\
\hline
\end{tabular}

\subsection{ARDL Bound Cointegration Test}

We used the ARDL bound cointegration test to examine the existence of a cointegration relationship among macroeconomic factors and road traffic accident indicators. The chosen lag length was based on the Akaike information criterion (AIC). AIC displays superiority over other criteria because it exhibits better small sample properties [35]. The results of the cointegration test shown in Table 4 confirm that long-run cointegration exists among $\operatorname{InTE}$, $\operatorname{InTU}, \operatorname{InTMH}, \operatorname{In} \mathrm{PVO}$, and road traffic accident indicators. However, the cointegration relationship between InAS and road traffic accident indicators is uncertain, because the value of the bound test F-statistic is 3.3262, which is between the upper and lower critical bounds. A study of traffic accidents from Hong Kong [36] also found that the impact of GDP on traffic accidents was ambiguous.

Table 4. Results of ARDL bound testing.

\begin{tabular}{|c|c|c|c|c|c|}
\hline Model & $\begin{array}{l}\text { Lag Length Based } \\
\text { on AIC }\end{array}$ & $\begin{array}{l}\text { Bound Test } \\
\text { F-Statistics }\end{array}$ & Significance & $\begin{array}{l}\text { Lower I(0) } \\
\text { Bound }\end{array}$ & $\begin{array}{l}\text { Upper } I(1) \\
\text { Bound }\end{array}$ \\
\hline $\begin{array}{c}\text { In AS = } f(\text { InRTA, } \\
\text { In } n \text { N , InFA, In } n \text { DEL })\end{array}$ & $\operatorname{ARDL}(1,2,2,2,1)$ & 3.3262 & $5 \%$ & 3.05 & 3.97 \\
\hline $\begin{array}{c}\operatorname{In} \mathrm{EM}=f(\operatorname{In} \mathrm{RTA} \\
\text { In } \mathrm{IN}, \text { In } \mathrm{FA}, \text { In } \mathrm{DEL})\end{array}$ & $\operatorname{ARDL}(1,0,1,2,2)$ & 163.5342 & $1 \%$ & 3.74 & 5.06 \\
\hline $\begin{array}{c}\text { In } \mathrm{UE}=f(\operatorname{In} \mathrm{RTA} \\
\text { In } \\
\mathrm{IN}, \text { In } \mathrm{FA}, \text { In } n \mathrm{DEL})\end{array}$ & $\operatorname{ARDL}(1,2,1,1,1)$ & 8.3385 & $1 \%$ & 3.81 & 4.92 \\
\hline $\begin{array}{l}I n \mathrm{TMH}=f(\operatorname{In} \mathrm{RTA}, \\
I n \mathrm{IN}, \operatorname{In} \mathrm{FA}, \text { In } \mathrm{DEL})\end{array}$ & $\operatorname{ARDL}(1,2,2,2,2)$ & 74.7924 & $1 \%$ & 3.07 & 4.44 \\
\hline $\begin{array}{l}\text { InPVO }=f(\text { In } \mathrm{RTA}, \\
\text { In } \mathrm{IN}, \text { In FA, InDEL })\end{array}$ & $\operatorname{ARDL}(2,2,0,1,0)$ & 5.9826 & $1 \%$ & 3.07 & 4.44 \\
\hline
\end{tabular}

\subsection{Estimation of Long- and Short-Run Dynamics}

The long-run and short-run dynamics for macroeconomic factors and road traffic accident indicators in China were estimated using the ARDL and ECM model. The results of long-run estimations are shown in Table 5, and short-run estimations are shown in Table 6. 
Table 5. Long-run estimations.

\begin{tabular}{|c|c|c|c|c|c|c|c|c|}
\hline \multirow{3}{*}{$\begin{array}{l}\text { Dependent } \\
\text { Variables } \\
\text { Independent } \\
\text { Variables }\end{array}$} & \multicolumn{2}{|c|}{ In EM } & \multicolumn{2}{|c|}{ InUE } & \multicolumn{2}{|c|}{ InTMH } & \multicolumn{2}{|c|}{ InPVO } \\
\hline & \multicolumn{2}{|c|}{ Lag Order $(1,0,1,2,2)$} & \multicolumn{2}{|c|}{$\operatorname{Lag} \operatorname{Order}(1,2,1,1,1)$} & \multicolumn{2}{|c|}{$\operatorname{Lag} \operatorname{Order}(1,2,2,2,2)$} & \multicolumn{2}{|c|}{ Lag Order $(2,2,0,1,0)$} \\
\hline & Coefficient & $t$-Statistic & Coefficient & $t$-Statistic & Coefficient & $t$-Statistic & Coefficient & $t$-Statistic \\
\hline InRTA & $-0.0847^{* * *}$ & -7.6256 & $0.3954 * *$ & 2.8726 & $-1.1212 * * *$ & -4.2545 & 12.4637 & 0.8872 \\
\hline InIN & $0.1196^{* * *}$ & 3.9201 & $-0.5492 *$ & -2.4010 & $-1.8217 * *$ & -3.8434 & -18.4985 & -1.2762 \\
\hline InFA & $-0.1454^{* * *}$ & -4.7967 & 0.223 & 1.2596 & $3.3855 * * *$ & 10.4211 & 14.5688 * & 1.8458 \\
\hline In $\mathrm{DEL}$ & $0.0314^{* * *}$ & 10.2691 & $-0.1251^{* *}$ & -2.4603 & $0.4314^{* * *}$ & 4.8703 & -6.3795 & -0.9322 \\
\hline $\mathrm{T}$ & & & $0.0154^{* * *}$ & 5.5707 & & & & \\
\hline
\end{tabular}

Table 6. Short-run estimations.

\begin{tabular}{|c|c|c|c|c|c|c|c|c|}
\hline \multirow{2}{*}{$\begin{array}{l}\text { Independent } \\
\text { Variables } \\
\text { Dependent } \\
\text { Variables }\end{array}$} & \multicolumn{2}{|c|}{ In EM } & \multicolumn{2}{|c|}{ InUE } & \multicolumn{2}{|c|}{ InTMH } & \multicolumn{2}{|c|}{ InPVO } \\
\hline & Coefficient & $t$-Statistic & Coefficient & $t$-Statistic & Coefficient & $t$-Statistic & Coefficient & $t$-Statistic \\
\hline $\mathrm{C}$ & $2.7694^{* * *}$ & 35.9001 & $6.5080^{* * *}$ & 9.6169 & & & & \\
\hline $\mathrm{D}(\operatorname{InPOV}(-1))$ & & & & & & & $0.6930^{* * *}$ & 13.7840 \\
\hline $\mathrm{D}(\operatorname{InRTA})$ & & & -0.0692 & -0.7199 & $0.5997^{* * *}$ & 9.1133 & $0.4609^{* * *}$ & 6.3802 \\
\hline $\mathrm{D}(\operatorname{In} \mathrm{RTA}(-1))$ & & & $-0.1678^{* *}$ & -3.5285 & $-0.4996^{* * *}$ & -4.7462 & $-0.1360 * * *$ & -4.7498 \\
\hline $\mathrm{D}(\operatorname{In} \mathrm{IN})$ & $0.0184^{* * *}$ & 17.6991 & -0.1543 & -1.7276 & $-1.2031 * * *$ & -16.5300 & & \\
\hline $\mathrm{D}(\operatorname{In} \mathrm{IN}(-1))$ & & & & & $0.7869 * * *$ & 9.4150 & & \\
\hline $\mathrm{D}(\operatorname{In} \mathrm{FA})$ & -0.0004 & -0.2937 & -0.1354 & -1.6486 & $0.3029 * * *$ & 5.0018 & $0.1680 * *$ & 2.5484 \\
\hline $\mathrm{D}(\operatorname{In} \mathrm{FA}(-1))$ & $0.0118 * * *$ & 9.6067 & & & $-0.8598^{* * *}$ & -10.3410 & & \\
\hline $\mathrm{D}(\operatorname{In} \mathrm{DEL})$ & $0.0035^{* * *}$ & 6.0647 & 0.0204 & 0.4391 & $0.0760 *$ & 2.3187 & & \\
\hline $\mathrm{D}(\operatorname{In} \mathrm{DEL}(-1))$ & $-0.0032 * * *$ & -5.7597 & & & $-0.2752 * * *$ & -7.1043 & & \\
\hline $\operatorname{ECM}(-1)$ & $-0.2296 * * *$ & -35.8457 & $-0.8614^{* * *}$ & -9.5772 & $-0.7356^{* * *}$ & -25.9448 & $-0.0216^{* * *}$ & -6.5733 \\
\hline
\end{tabular}

Over the long term, EM is negatively correlated with RTA and FA; for every $1 \%$ increase in EM, RTA and FA reduce by $0.085 \%$ and $0.145 \%$, respectively. In the contrary, EM is positively correlated with IN and DEL; for every $1 \%$ increase in EM, IN and DEL rise by $0.12 \%$ and $0.031 \%$, respectively. The opposite stands true for the long-term estimates of UE; within the $10 \%$ significance, every $1 \%$ increase in UE is associated with a $0.395 \%$ rise in RTA, and decreases of $0.549 \%$ and $0.125 \%$, respectively, in IN and DEL. Such a result indicates that China's economic growth is able to effectively inhibit the total number of traffic accidents. However, from the perspective of accident severity, a high employment rate is associated with a greater number of injuries caused by traffic accidents despite its effectiveness in reducing the number of traffic accident-related deaths during the times of economic prosperity. Economic recession and increased unemployment rate tend to result in a higher drunk driving rate, thereby inducing a rise in fatalities [37]. A similar pattern was also confirmed by De la Fuente [38] in his study of occupational accidents in Spain, which found that while deaths from accidents were effectively inhibited during times of economic prosperity, the number of accident injuries actually increased. Thus, taking severity into account when discussing the effects of economic growth on accidents would generate more accurate and valuable results from a practical point of view.

There is a significant correlation between $\mathrm{TMH}, \mathrm{PVO}$, and road traffic accident indicators in the long-run dynamics. A $1 \%$ increase of TMH leads to a $1.1212 \%$ and $1.8217 \%$ decrease in RTA and IN, respectively, and leads to a $3.3855 \%$ and $0.4314 \%$ increase in FA and DEL, respectively. Within the $10 \%$ significance, every $1 \%$ increase in PVO is associated with a $0.146 \%$ rise in FA. The increase in the total length of highway reduces the number of road traffic accidents and the resultant injuries; however, in the meantime, it also increases the number of over-speeding and reckless driving behaviors, thereby causing a rise in accident fatalities. Such a phenomenon is also confirmed by a Sweden-specific study conducted by Niclas A. Krüger [22]. Similarly, an increase in household income during times of economic prosperity stimulates people's desire to purchase vehicles [39]. Consistent with Ahangari's [40] study, an increase in vehicle ownership results in greater numbers of accident fatalities along with the expansion in the market of private vehicles. 
As listed in Table 5, the short-run estimations report a significant relationship of TE, TU, TMH, and PVO with traffic accident indicators. For both TE and PVO, the short-run estimated coefficients of all road traffic accident indicators are significantly smaller than the long-run estimated coefficients. It shows that the long-term impact of TE and PVO on traffic accident indicators is greater than the short-term impact. The impact of TU and traffic accident indicators is insignificant in the short-run dynamics, although they have a significant link in the long-run dynamics. With respect to TMH, the short-term coefficients of all traffic accident indicators are invariably smaller than their long-term counterparts, but the lagging traffic accident indicators across different orders exhibit alternatively positive and negative effects on the current $\mathrm{TMH}$, trending towards a salient effect over the long term.

All the ECM coefficients are negative and highly significant, implying macroeconomic factors and road traffic accident indicators have the ability to converge back to a long-term equilibrium after a short-term shock.

We used the cumulative sum (CUSUM) and cumulative sum of squares (CUSUMSQ) tests to verify the stability of the parameters in the ECM model. The results are shown in Figures 6 and 7, respectively. The figures indicate that the study model is a good fit because both the CUSUM plots and CUSUMSQ plots lie within the critical bounds at the $5 \%$ significance level.
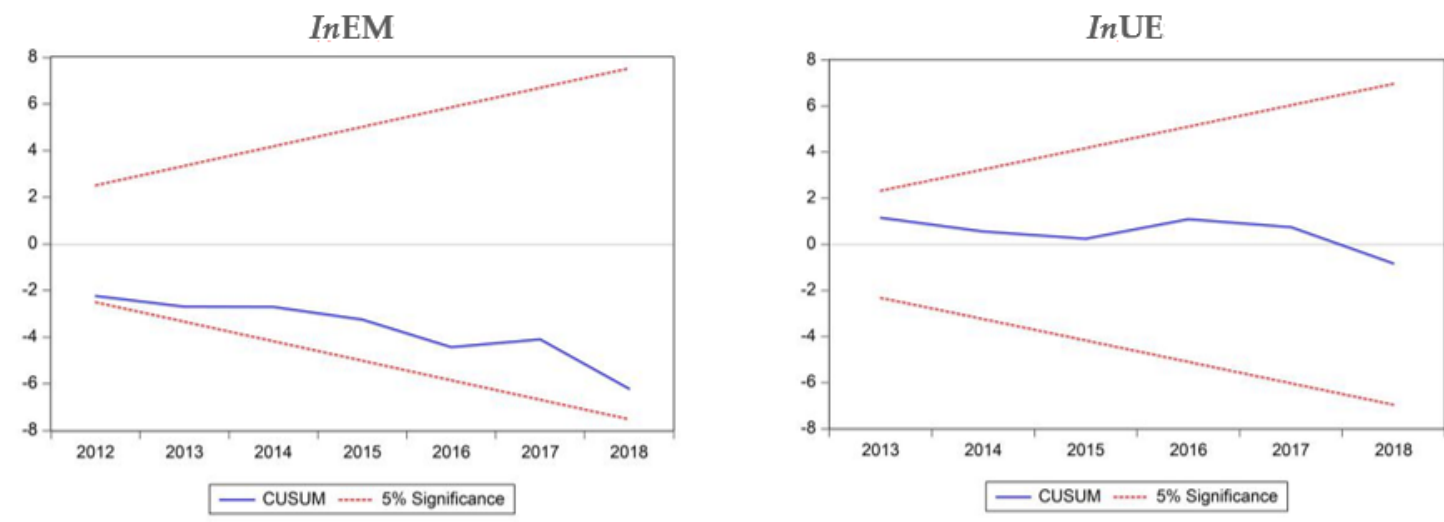

$\operatorname{In} \mathrm{TMH}$
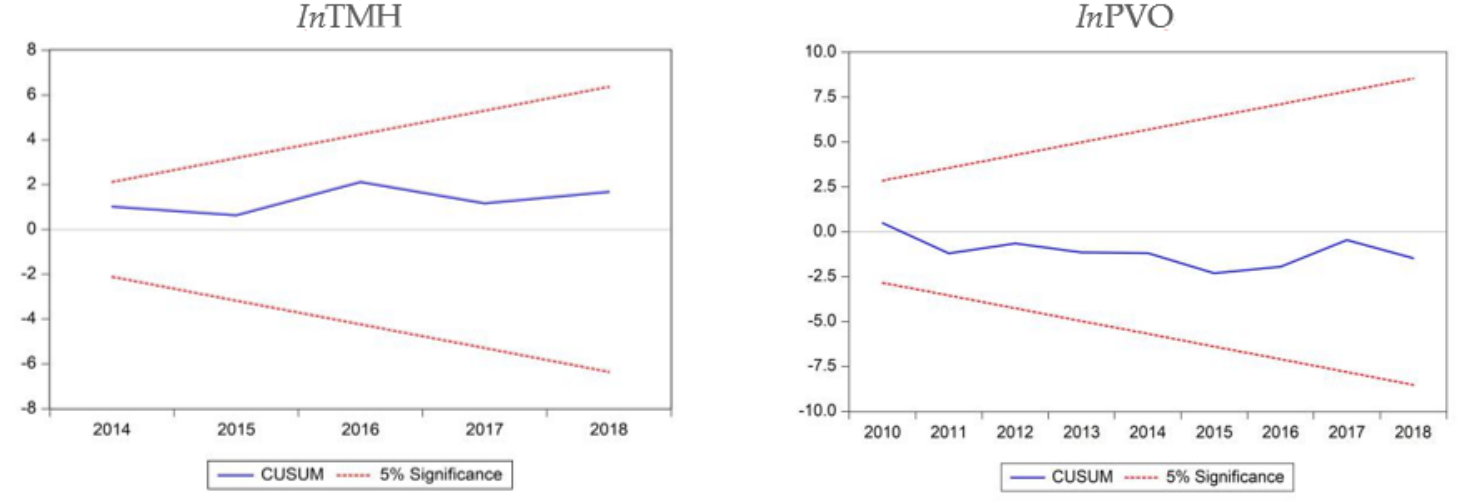

Figure 6. Plots of cumulative sum (CUSUM). 

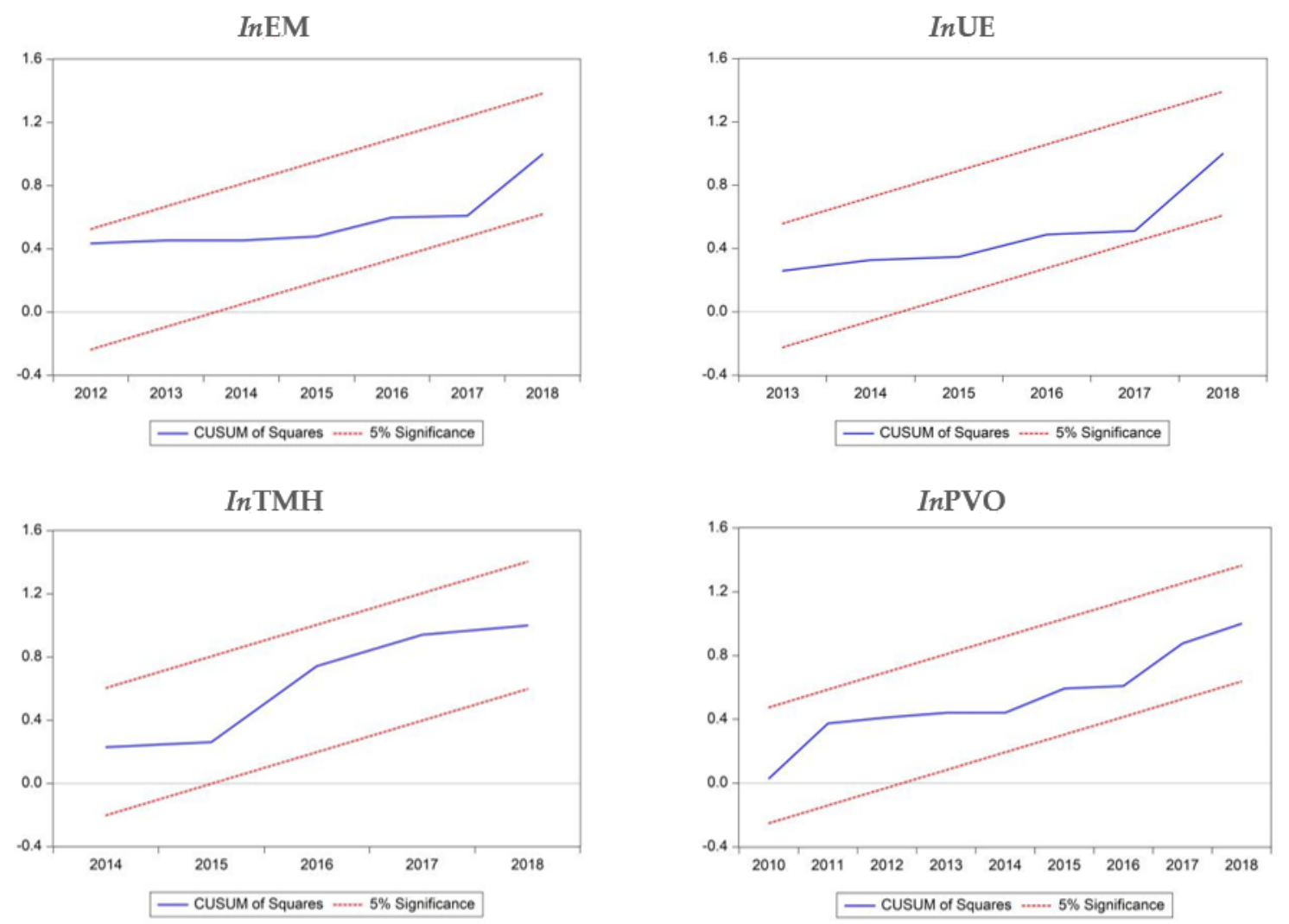

Figure 7. Plots of cumulative sum of squares (CUSUMSQ).

\subsection{Granger Causality Tests within the VECM Framework}

The results of the Granger causality test within the VECM framework are discussed in this section, which are shown in Tables 7 and 8. In the short term, we found the following results:

1. There is a short-run single directional causality from EM to IN at 5\% significance level. Consistent with the short-term estimates, an increase in the number of employed persons leads to a rise in injuries caused by road traffic accidents. Studies show that economic volatility causes changes in drivers' behaviors [41], and risky driving behaviors tend to increase during times of economic growth [42], thereby leading to a rise in accident injuries. Furthermore, drivers are more inclined to have inattentive behaviors when traveling along familiar road sections [43]; an increase in the number of employed persons brings forth noticeable commuting peaks and highly congested urban traffic; monotonous and repeated commuting routes, as well as inattentive drivers, are more likely to induce accidents predominated by injuries [44]. As shown in Figure 2a, the rise of socioeconomic levels in China over recent years has been accompanied not only by enhanced awareness of environmental protection, but also by the share of commuting via non-motorized vehicles thanks to the designated lanes for shared bikes and non-motorized vehicles, resulting in a significant increase in injuries caused by non-motorized vehicle accidents.

2. There is evidence of supporting a short-run single directional causality from PVO to FA. The result of the Granger causality test shows that, over the short term, an increase in private vehicle ownership leads to a rise in fatalities from road traffic accidents at $10 \%$ significance level. As shown in Figure $2 b$, the share of fatalities caused by motorized vehicle accidents over the past 20 years, which represent the major type of fatal accident in the country, rose to $75 \%$ in 2018 from $60 \%$ in 1999 . This further confirms that increased motorized vehicle ownership leads to a year-over-year increase in fatalities from road traffic accidents. With the increase in private 
vehicle ownership, more people have obtained driver's licenses, and the entry of novice drivers onto roads constitutes one of the most important factors causing the rise in accident fatalities [45].

3. In the short term, a single directional causality relationship is found from RTA, IN, and FA to TMH. Over the short term, the volatility in road traffic accidents will affect changes in the total length of highway, indicating that road traffic safety is an important premise for the development of road traffic; the increase in the number of road traffic accidents, the number of fatalities and injuries will exert an influence on road traffic planning and decision-making by management authorities, thereby inhibiting the growth in the total length of highway over the short term.

Table 7. Granger causality results.

\begin{tabular}{|c|c|c|c|c|}
\hline \multirow{2}{*}{ Dependent Variables } & \multicolumn{4}{|c|}{ Independent Variables F-Statistics ( $p$-Values) } \\
\hline & $\mathrm{D}(\operatorname{In} \mathrm{EM})$ & $\mathrm{D}(\operatorname{In} \mathrm{UE})$ & $\mathrm{D}(\operatorname{In} \mathrm{TMH})$ & D(InPVO) \\
\hline $\mathrm{D}(\operatorname{In} \mathrm{RTA})$ & $0.2348(0.6280)$ & $0.6370(0.4248)$ & $0.5548(0.4564)$ & $1.3436(0.2464)$ \\
\hline $\mathrm{D}(\operatorname{InIN})$ & $3.8926 * *(0.0485)$ & $1.1987(0.1660)$ & $0.4299(0.5120)$ & $0.5498(0.4584)$ \\
\hline $\mathrm{D}(\operatorname{In} \mathrm{FA})$ & $2.2128(0.1369)$ & $0.0364(0.8486)$ & $0.1832(0.6686)$ & $3.3122 *(0.0688)$ \\
\hline $\mathrm{D}(\operatorname{In} \mathrm{DEL})$ & $0.0632(0.8014)$ & $0.0720(0.7884)$ & $1.2461(0.2643)$ & $0.5726(0.4492)$ \\
\hline
\end{tabular}

Table 8. Granger causality results.

\begin{tabular}{|c|c|c|c|c|}
\hline \multirow{2}{*}{ Dependent Variables } & \multicolumn{4}{|c|}{ Independent Variables F-Statistics ( $p$-Values) } \\
\hline & $\mathrm{D}(\operatorname{In} \mathrm{RTA})$ & $\mathrm{D}(\operatorname{InIN})$ & $\mathrm{D}(\operatorname{InFA})$ & $\mathrm{D}(\operatorname{In} \mathrm{DEL})$ \\
\hline $\mathrm{D}(\operatorname{In} \mathrm{EM})$ & $0.4783(0.4892)$ & $0.9705(0.3246)$ & $0.0511(0.8211)$ & $0.0035(0.9526)$ \\
\hline $\mathrm{D}(\operatorname{InUE})$ & $2.1809(0.1397)$ & $0.8577(0.3544)$ & $0.0176(0.8944)$ & $1.9496(0.1626)$ \\
\hline $\mathrm{D}(\operatorname{In} \mathrm{TMH})$ & $12.3474 * * *(0.0004)$ & $17.0718^{* * *}(0.0000)$ & $4.6102 * *(0.0318)$ & $0.4144(0.5197)$ \\
\hline $\mathrm{D}(\operatorname{InPVO})$ & $0.1639(0.6856)$ & $0.6144(0.4331)$ & $1.1949(0.2743)$ & $0.0329(0.8560)$ \\
\hline
\end{tabular}

\section{Conclusions}

This study aimed to test whether economic volatility exerts differentiated effects on indicators and losses pertaining to road traffic accidents. To that end, we examined China's road traffic accidents spanning from 1999 to 2018 and discussed the different effects of five commonly used economic indicators, namely, average salaries, employment, unemployment, total mileage of highway, and private vehicle ownership, on the number of road traffic accidents, injuries, fatalities, and direct economic losses, followed by an investigation of the long-term equilibrium and short-term interactions among these indicators using the ARDL-ECM model. We found that all economic indicators except average salaries have a long-term equilibrium with road traffic accident indicators, and their long-term relationships are more salient than their counterparts over the short term. Specifically, employment is negatively correlated with road traffic accidents and that of fatalities, but positively correlated with injuries and direct economic losses. For every $1 \%$ increase in employment, the road traffic accidents and fatalities decrease by $0.085 \%$ and $0.145 \%$, respectively, whereas injuries and direct economic losses increase by $0.12 \%$ and $0.031 \%$, respectively. The opposite stands true for the relationship between unemployment and these road traffic accident indicators; for every $1 \%$ increase in unemployment, road traffic accidents increase by $0.395 \%$, but injuries and direct economic losses decrease by $0.549 \%$ and $0.125 \%$, respectively. The total mileage of highway and road traffic accidents are negatively correlated with injuries, but positively correlated with fatalities and direct economic losses. For every $1 \%$ increase in the total mileage of highway, road traffic accidents and injuries decrease by $1.121 \%$ and $1.822 \%$, respectively, whereas fatalities and direct economic losses increase by $3.386 \%$ and $0.431 \%$, respectively. Private vehicle ownership is positively correlated with fatalities; for every $1 \%$ increase in private vehicle ownership, fatalities increase by $0.146 \%$. The Granger causality test showed that, 
over the short term, an increase in employment could lead to an increase in injuries, an increase in private vehicle ownership results in a rise in fatalities, and the short-term variations in road traffic accidents, injuries, and fatalities directly affect changes in the total mileage of highway.

We found that volatility in economic indicators exerts significantly different effects on road traffic accidents, injuries, and fatalities. Such a finding may help us to establish preventative measures that are more economically efficient.

\subsection{Employment and Road Traffic Safety}

Our study finds that poor employment prospects lead to an increase in road traffic accidents and fatalities, while improvements in employment further lead to an increase in injuries and direct economic losses. We recommend that greater legislative efforts should be pursued in times of economic recessions to regulate drunk driving and over-speeding, reduce upper speed limits of highways, and standardize the use of safety belts in order to avoid the occurrence of fatal accidents. When the employment rate increases, more efforts should be put into providing publicity and guidance related to public safety, especially during peak commuting hours and at places like crossroads that involve high pedestrian and vehicle flows [46]. A good cultural atmosphere revolving around traffic safety should also be created in order to raise people's safety awareness and prevent the occurrence of injury accidents [47].

\subsection{Total Mileage of Highway and Road Traffic Safety}

Over the short term, the frequent occurrences of road traffic accidents will inhibit the increase in the total mileage of highway. A failure to effectively control the occurrences of these accidents may affect the overall decision-making taking place in local governments and relevant management authorities over the short term, thereby producing a negative impact on the development of regional road traffic. To address the issue, we recommend that protection fences be erected for different types of road sections to raise the level of road traffic safety, on the one hand [48], and warning signs should also be put up around areas entailing frequent occurrences of accidents, on the other hand. Improvements in road traffic can only be achieved by ensuring the conscientious development of road traffic safety.

\subsection{Private Vehicle Ownership and Road Traffic Safety}

Over the long term, private vehicle ownership is positively correlated with road traffic accidents, and a short-term increase in private vehicle ownership inevitably leads to a rise in fatalities. To avoid the rise in fatalities caused by increased private vehicle ownership, approaches like increasing the difficulty in obtaining drivers' licenses or setting up classified drivers' licenses can be implemented in order to increase drivers' proficiency and avoid high accident rates caused by novice drivers [49]. Additionally, studies have shown that risky driving behaviors such as the frequent use of mobile phones also increase the fatality rate of non-professional drivers [50]. Thus, such behaviors can be reduced through the implementation of an electronic policing system or the provision of adequate publicity and guidelines.

Our research has some limitations. On the one hand, the data we collected are from 1999 to 2018, which lacks timeliness. On the other hand, a significant number of macroeconomic data were collected to support this study, but several factors were not considered in the analysis, such as the composition of road traffic, considering "heavy injuries" and "light injuries" separately. In the following studies, we will continue to use more econometric methods to examine the cointegration between road traffic accident indicators and macroeconomic factors and compare the differences between these methods.

Author Contributions: Writing-original draft preparation, X.L. (Xibing Li) and J.L.; methodology, J.Z.; supervision, L.Z.; data curation, X.L. (Xiling Liu); project administration, W.W. All authors have read and agreed to the published version of the manuscript.

Funding: This research was partially supported by the National Natural Science Foundation Project of China (Grant nos. 41630642 and 5192780). 
Conflicts of Interest: The authors declare no conflict of interest.

\section{References}

1. Stojanová, H.; Blašková, V. Cost benefit study of a safety campaign's impact on road safety. Accid. Anal. Prev. 2018, 117, 205-215. [CrossRef] [PubMed]

2. World Health Organisation. Global Status Report on Road Safety. 2018. Available online: https://www.who. int/publications/i/item/9789241565684 (accessed on 7 December 2020).

3. Sánchez González, M.P.; Tejada Ponce, Á.; Escribano Sotos, F. Interregional inequality and road accident rates in Spain. Accid. Anal. Prev. 2020, 135, 105347. [CrossRef] [PubMed]

4. Sakhapov, R.; Nikolaeva, R. Economic aspects of traffic safety administration. Transp. Res. Procedia 2017, 20, 578-583. [CrossRef]

5. Bougueroua, M.; Carnis, L. Economic development, mobility and traffic accidents in Algeria. Accid. Anal. Prev. 2016, 92, 168-174. [CrossRef] [PubMed]

6. Yannis, G.; Papadimitriou, E.; Folla, K. Effect of GDP changes on road traffic fatalities. Saf. Sci. 2014, 63, 42-49. [CrossRef]

7. Wiebe, D.J.; Ray, S.; Maswabi, T.; Kgathi, C.; Branas, C.C. Economic development and road traffic fatalities in two neighbouring African nations. Afr. J. Emerg. Med. 2016, 6, 80-86. [CrossRef]

8. Dadgar, I.; Norström, T. Short-term and long-term effects of GDP on traffic deaths in 18 OECD countries, 1960-2011. J. Epidemiol. Commun. Health 2017, 71, 146-153. [CrossRef]

9. Rodríguez-López, J.; Marrero, G.A.; González, R.M.; Leal-Linares, T. Road accidents and business cycles in Spain. Accid. Anal. Prev. 2016, 96, 46-55. [CrossRef]

10. Antoniou, C.; Yannis, G.; Papadimitriou, E.; Lassarre, S. Relating traffic fatalities to GDP in Europe on the long term. Accid. Anal. Prev. 2016, 92, 89-96. [CrossRef]

11. Nghiem, S.; Commandeur, J.J.F.; Connelly, L.B. Determinants of road traffic safety: New evidence from Australia using state-space analysis. Accid. Anal. Prev. 2016, 94, 65-72. [CrossRef]

12. Kweon, Y.J. What affects annual changes in traffic safety? A macroscopic perspective in Virginia. J. Saf. Res. 2015, 53, 17-21. [CrossRef] [PubMed]

13. Castillo-Manzano, J.I.; Castro-Nuno, M.; Lopez-Valpuesta, L.; Boby, J. Looking for traces of the Troika's intervention in European road safety. Accid. Anal. Prev. 2020, 137, 105461. [CrossRef] [PubMed]

14. Nghiem, H.S.; Connelly, L.B.; Gargett, S. Are road traffic crash fatality rates converging among OECD countries? Accid. Anal. Prev. 2013, 52, 162-170. [CrossRef] [PubMed]

15. Law, T.H.; Noland, R.B.; Evans, A.W. The sources of the Kuznets relationship between road fatalities and economic growth. J. Transp. Geogr. 2011, 19, 355-365. [CrossRef]

16. Strukcinskiene, B.; Martinkenas, A.; Towner, E.; Janson, S.; Andersson, R. Traffic injury mortality in children in transitional Lithuania-A longitudinal analysis from 1971 to 2005. Acta. Paediatr. 2008, 97, 358-361. [CrossRef]

17. Law, T.H. Factors associated with the relationship between non-fatal road injuries and economic growth. Transp. Policy 2015, 42, 166-172. [CrossRef]

18. Jusuf, A.; Nurprasetio, I.P.; Prihutama, A. Macro data analysis of traffic accidents in Indonesia. J. Eng. Technol. Sci. 2017, 49, 132-143. [CrossRef]

19. Rojo, M.; Gonzalo-Orden, H.; Linares, A.; Dell'Olio, L. Impact of a lower conservation budget on road safety Indices. J. Adv. Transp. 2018, 2018, 1-9. [CrossRef]

20. Sun, L.; Liu, D.; Chen, T.; He, M. Analysis on the accident casualties influenced by several economic factors based on the traffic-related data in China from 2004 to 2016. Chin. J. Traumatol. 2019, 22, 75-79. [CrossRef] [PubMed]

21. Saar, I. Do alcohol excise taxes affect traffic accidents? Evidence from Estonia. Traffic. Inj. Prev. 2015, 16, 213-218. [CrossRef] [PubMed]

22. Krüger, N.A. Fatal connections-socioeconomic determinants of road accident risk and drunk driving in Sweden. J. Saf. Res. 2013, 46, 59-65. [CrossRef]

23. Traynor, T.L. The impact of state level behavioral regulations on traffic fatality rates. J. Saf. Res. 2009, 40, 421-426. [CrossRef] 
24. Mamčic, S.; Sivilevičius, H. The analysis of traffic accidents on Lithuanian regional gravel roads. Transp. Vilnius 2013, 28, 108-115. [CrossRef]

25. World Health Organisation. Global Status Report on Road Safety. 2015. Available online: http://www.who. int/violence_injury_prevention/road_safety_status/2015/en/(accessed on 7 December 2020).

26. Wang, X.; Zhou, Q.; Yang, J.; You, S.; Song, Y.; Xue, M. Macro-level traffic safety analysis in Shanghai, China. Accid. Anal. Prev. 2019, 125, 249-256. [CrossRef]

27. National Bureau of Statisitics. Available online: http://www.stats.gov.cn/ (accessed on 7 December 2020).

28. Engle, R.F.; Granger, C.W. Co-integration and error correction: Representation, estimation, and testing. Econom. J. Econom. Soc. 1987, 55, 251-276. [CrossRef]

29. Johnsen, S. Statistical analysis of cointegration vectors. J. Econ. Dyn. Control 1988, 2-3, 231-254. [CrossRef]

30. Pesaran, M.H.; Shin, Y.C.; Smith, R.J. Bounds testing approaches to the analysis of level relationships. J. Appl. Econ. 2001, 16, 289-326. [CrossRef]

31. Johansen, S. Estimation and hypothesis testing of cointegration vectors in Gaussian vector autoregressive models. Econom. J. Econ. Soc. 1991, 59, 1551-1580. [CrossRef]

32. Granger, C.W. Investigating causal relations by econometric models and cross-spectral methods. Econometrica 1969, 3, 424-438. [CrossRef]

33. Dickey, D.A.; Fuller, W.A. Likelihood ratio statistics for autoregressive time series with unit root. Econometrica 1981, 4, 1057-1072. [CrossRef]

34. Phillips, P.B.; Perron, P. Testing for a unit root in time series regression. Biometrika 1988, 2, 335-346. [CrossRef]

35. Brueggemann, R.; Luetkepohl, H.; Saikkonen, P. Residual autocorrelation testing for vector error correction models. J. Econom. 2006, 134, 579-604. [CrossRef]

36. Li, X.; Wu, L.; Yang, X. Exploring the impact of social economic variables on traffic safety performance in Hong Kong: A time series analysis. Saf. Sci. 2018, 109, 67-75. [CrossRef]

37. Ying, Y.; Wu, C.; Chang, K. The effectiveness of drinking and driving policies for different alcohol-related fatalities: A quantile regression analysis. Int. J. Environ. Res. Pub. Health 2013, 10, 4628-4644. [CrossRef] [PubMed]

38. de la Fuente, V.S.; López, M.A.C.; González, I.F.; Alcántara, O.J.G.; Ritzel, D.O. The impact of the economic crisis on occupational injuries. J. Saf. Res. 2014, 48, 77-85. [CrossRef]

39. Ritter, N.; Vance, C. Do fewer people mean fewer cars? Population decline and car ownership in Germany. Transp. Res Pol. Pract. 2013, 50, 74-85. [CrossRef]

40. Ahangari, H.; Outlaw, J.; Atkinson-Palombo, C.; Garrick, N.W. Investigation into impact of fluctuations in gasoline prices and macroeconomic conditions on road safety in developed countries. Transp. Res. Rec. 2014, 2465, 48-56. [CrossRef]

41. De Oña, J.; de Oña, R.; Eboli, L.; Forciniti, C.; Machado, J.L.; Mazzulla, G. Analysing the relationship Among accident severity, drivers' behaviour and their socio-economic characteristics in different territorial contexts. Procedia Soc. Behav. Sci. 2014, 160, 74-83. [CrossRef]

42. Lloyd, L.; Wallbank, C.; Broughton, J. A collection of evidence for the impact of the economic recession on road fatalities in Great Britain. Accid. Anal. Prev. 2015, 80, 274-285. [CrossRef]

43. Colonna, P.; Intini, P.; Berloco, N.; Ranieri, V. The influence of memory on driving behavior: How route familiarity is related to speed choice. An on-road study. Saf. Sci. 2016, 82, 456-468. [CrossRef]

44. Gray, R.C.; Quddus, M.A.; Evans, A. Injury severity analysis of accidents involving young male drivers in Great Britain. J. Saf. Res. 2008, 39, 483-495. [CrossRef] [PubMed]

45. Walton, D.; Jenkins, D.; Thoreau, R.; Kingham, S.; Keall, M. Why is the rate of annual road fatalities increasing? A unit record analysis of New Zealand data (2010-2017). J. Saf. Res. 2020, 72, 67-74. [CrossRef] [PubMed]

46. Noland, R.B.; Adediji, Y. Are estimates of crash modification factors mis-specified? Accident. Anal. Prev. 2018, 118, 29-37. [CrossRef] [PubMed]

47. Naevestad, T.; Bjornskau, T. How Can the safety culture perspective be applied to road traffic? Transp. Rev. 2012, 32, 139-154. [CrossRef]

48. Butans, Z.; Gross, K.A.; Gridnevs, A.; Karzubova, E. Road safety barriers, the need and influence on road traffic accidents. In Proceedings of the IOP Conference Series-Materials Science and Engineering, International Conference on Innovative Materials, Structures and Technologies, Riga, Latvia, 30 September-2 October 2015; Volume 96. 
49. Bates, L.; Rodwell, D.; Matthews, S. Young driver enforcement within graduated driver licensing systems: A scoping review. Crime Prev. Community Saf. 2019, 21, 116-135. [CrossRef]

50. Choudhary, P.; Velaga, N.R. Effects of phone use on driving performance: A comparative analysis of young and professional drivers. Saf. Sci. 2019, 111, 179-187. [CrossRef]

Publisher's Note: MDPI stays neutral with regard to jurisdictional claims in published maps and institutional affiliations.

(C) 2020 by the authors. Licensee MDPI, Basel, Switzerland. This article is an open access article distributed under the terms and conditions of the Creative Commons Attribution (CC BY) license (http://creativecommons.org/licenses/by/4.0/). 